\title{
Gambaran kadar urea nitrogen darah pada vegetarian lacto-ovo
}

\author{
${ }^{1}$ Jeri Y. The \\ ${ }^{2}$ Michaela E. Paruntu \\ ${ }^{2}$ Youla A. Assa
}

\author{
${ }^{1}$ Kandidat Skripsi Fakultas Kedokteran Universitas Sam Ratulangi Manado \\ ${ }^{2}$ Bagian Biokimia Fakultas Kedokteran Universitas Sam Ratulangi Manado \\ Email: jeriyantothe12242@yahoo.com
}

\begin{abstract}
Protein is required to provide amino acids for nitrogen formation. Urea is the major disposal form of amino groups derived from amino acids. The nitrogen of urea is derived from amonia and aspartatedue to the action of five enzyme-catalyzed reactions of urea cycle. Concentration of urea in blood mainly describes the balance between formation of urea and protein catabolism as well as urea excretion by the kidneys. Vegetarian lacto-ovo is a type of vegetarians who does not consume animal proteins except for milk and eggs, and all plant proteins. This study aimed to obtain blood urea levels among lacto-ovo vegetarians. This was a descriptive study with a cross-sectional design. Respondents were obtained by using total sampling method. This study was coducted in Klabat University, Airmadidi. Twentyfive respondents were involved in the study. The results showed that 19 respondents $(76.0 \%)$ had normal blood urea level and 6 respondents (20\%) had low blood urea levels; no respondent (0\%) had a high blood urea level. Conclusion: Blood urea levels of most lacto-ovo vegetarians were within normal level.
\end{abstract}

Keyword: urea nitrogen, protein, lacto-ovo vegetarian

\begin{abstract}
Abstrak: Protein dibutuhkan untuk menyediakan asam amino yang akan digunakan untuk memroduksi senyawa nitrogen sebagai penggganti nitrogen yang telah dikeluarkan dari tubuh dalam bentuk urea. Urea merupakan produk akhir dari metabolisme nitrogen yang penting pada manusia yang disintesis dari amonia, dan aspartat melalui lima reaksi enzim-katalis dari siklus urea. Konsentrasi urea dalam darah terutama menggambarkan keseimbangan antara pembentukan urea dan katabolisme protein serta ekskresi urea oleh ginjal. Vegetarian lactoovo yaitu vegetarian yang tidak mengonsumsi sumber protein hewani selain susu, telur, dan juga mengonsumsi semua sumber protein nabati. Penelitian ini bertujuan untuk mengetahui gambaran kadar urea darah pada vegetarian lacto-ovo. Jenis penelitian ini deskriptif dengan desain potong lintang. Penelitian ini dilakukan di Universitas Klabat Airmadidi. Terdapat 25 responden yang diperoleh melalui total sampling. Hasil penelitian mendapatkan 19 responden (76,0\%) dengan kadar urea darah normal dan 6 responden (20\%) dengan kadar urea darah rendah; tidak ditemukan responden (0\%) dengan kadar urea darah tinggi. Simpulan: Gambaran kadar urea nitrogen darah pada vegetarian lacto-ovo sebagian besar normal.
\end{abstract}

Kata kunci: urea nitrogen, protein, vegetarian lacto-ovo

Gaya hidup modern yang tidak sehat, diikuti dengan tidak teraturnya pola makan mengakibatkan tingkat kesehatan manusia semakin menurun. Menjamurnya masakan siap saji hingga penambahan bahan pengawet, pewarna, dan perasa buatan pada makanan, juga menjadi pemicu masalah kesehatan. Upaya yang dapat dilakukan manusia untuk bisa hidup sehat tanpa meninggalkan dunia modern yang dijalaninya adalah dengan berusaha menyelaraskan diri dengan alam. Salah satu 
cara yang dapat ditempuh yaitu dengan menerapkan pola makan vegetarian. ${ }^{1}$

Vegetarian adalah diet yang tidak mengomsumsi daging, ikan, dan unggas. ${ }^{2}$ Vegetarian lebih banyak mengonsumsi makanan jenis kacang-kacangan, bijibijian, sayuran, dan buah-buahan dengan mengurangi atau membatasi makanan dan minuman produk hewani. ${ }^{3}$ American Dietetic Association membagi vegetarian menjadi tiga jenis, yaitu: Vegan, lacto, dan salah satunya yang paling umum ditemui di kalangan masyarakat ialah vegetarian lacto-ovo.Vegetarian lacto-ovo merupakan tipe vegetarian yang paling umum ditemui. $^{4,5}$ Tipe ini tidak mengonsumsi segala jenis daging, baik daging ternak ataupun daging unggas dan juga ikan, tetapi masih mengonsumsi susu dan telur. ${ }^{5}$

Pada survei 1997 terdapat 1\% penduduk Amerika Serikat yang vegetarian, kemudian meningkat menjadi $2,5 \%$ pada tahun $2000,2,8 \%$ pada tahun 2003, dan pada tahun 2006 diperkirakan telah mencapai 30-40\%. Newspoll Phone Survey tahun 2010 melaporkan bahwa 2\% penduduk Australia ialah vegetarian. Di India pada tahun 2003, 50\% penduduknya ialah vegetarian. Indonesian Vegetarian Society (IVS) menunjukkan peningkatan jumlah anggota yang pesat dari 5.000 orang pada tahun 1998, menjadi 60.000 orang pada tahun $2007 .^{6}$

Nutrisi berperan dalam pertumbuhan, pemeliharaan, dan perbaikan tubuh termasuk di dalamnya protein. Bahanbahan makanan sumber protein pada vegetarian lacto ovo didapatkan dari susu, telur, dan produk-produk nabati. ${ }^{7}$ Protein dalam makanan diperlukan untuk menyediakan asam amino yang akan digunakan untuk memroduksi senyawa nitrogen yang lain, mengganti protein dalam jaringan yang mengalami proses penguraian, dan mengganti nitrogen yang telah dikeluarkan dari tubuh dalam bentuk urea. ${ }^{8}$ Urea nitrogen merupakan produk akhir dari metabolisme nitrogen yang penting pada manusia yang disintesis dari amonia, dan aspartat. Hampir seluruh urea dibentuk didalam hati, dari katabolisme asam-asam amino, dan merupakan produk ekskresi metabolisme protein yang utama. Konsentrasi urea nitrogen dalam darah terutama menggambarkan keseimbangan antara pembentukan urea nitrogen dan katabolisme protein serta ekskresi urea oleh ginjal. $^{9}$ Penelitian ini bertujuan untuk gambaran kadar urea nitrogen darah pada vegetarian lacto-ovo.

\section{METODE PENELITIAN}

Jenis penelitian ini ialah deskriptif dengan desain potong lintang untuk mengetahui gambaran kadar urea nitrogen darah pada vegetarian lacto-ovo. Penelitian ini dilakukan di Universitas Klabat Air Madidi pada bulan November 2015Januari 2016. Responden ialah 25 mahasiswa yang telah melakukan diet vegetarian lacto-ovo selama 6 bulan diperoleh dengan total sampling (kriteria inklusi). Sampel darah vena diperiksa di Laboratorium Klinik Prodia menggunakan metode pemeriksaan urease/GLDH untuk menilai kadar urea nitrogen darah dengan nilai normal dalam serum 6-20 mg/dL.

\section{HASIL PENELITIAN}

Berdasarkan hasil penelitian yang dilakukan di Universitas Klabat Air Madidi, didapatkan rentang usia responden 15-32 tahun berjumlah 25 orang (Tabel 1). Responden berjenis kelamin laki-laki berjumlah 14 orang (56,0\%) sedangkan yang berjenis kelamin perempuan berjumlah 11 orang (44,0\%).

Tabel 1. Distribusi Responden Berdasarkan Jenis Kelamin

\begin{tabular}{ccc}
\hline Jenis Kelamin & Jumlah & $\mathbf{( \% )}$ \\
\hline Laki-laki & 14 & 56,0 \\
Perempuan & 11 & 44,0 \\
Total & 25 & 100,0 \\
\hline
\end{tabular}

Pada Tabel 2 dapat dilihat bahwa proporsi tertinggi pada kelompok umur 1824 tahun sebanyak 15 orang (60,0\%), diikuti oleh kelompok umur 25-31 tahun sebanyak 8 orang (32,0\%), dan yang terendah pada kelompok umur kurang dari 
18 tahun dan lebih dari 31 tahun sebanyak 1 orang (4,0\%).

Tabel 2. Distribusi Sampel Berdasarkan Usia

\begin{tabular}{ccc}
\hline Umur & Jumlah & $(\%)$ \\
\hline$<18$ & 1 & 4,0 \\
$18-24$ & 15 & 60,0 \\
$25-31$ & 8 & 32,0 \\
$>31$ & 1 & 4,0 \\
Total & 25 & 100,0 \\
\hline
\end{tabular}

Tabel 3 memperlihatkan sebanyak 19 orang $(76,0 \%)$ dengan kadar urea nitrogen normal, 6 orang $(24,0 \%)$ dengan kadar urea nitrogen rendah, sedangkan untuk kadar urea nitrogen tinggi tidak ada (0\%).

Tabel 3. Distribusi Sampel Berdasarkan Kadar Urea Nitrogen Darah

\begin{tabular}{ccc}
\hline Kadar Urea & Jumlah & $(\%)$ \\
\hline Rendah & 6 & 24,0 \\
$(<6 \mathrm{mg} / \mathrm{dL})$ & & \\
Normal & 19 & 76,0 \\
$(6-20 \mathrm{mg} / \mathrm{dL})$ & & 0 \\
$\quad$ Tinggi & 0 & \\
$(>20 \mathrm{mg} / \mathrm{dL})$ & & 100,0 \\
Total & 25 &
\end{tabular}

Nilai mean atau rerata hasil pemeriksaan kadar urea nitrogen darah pada penelitian ini $6,72 \mathrm{mg} / \mathrm{dL}$ dengan standard deviasi $\pm 1,81$. Nilai median kadar urea nitrogen darah yaitu $6 \mathrm{mg} / \mathrm{dL}$. Nilai modus kadar urea nitrogen darah $6 \mathrm{mg} / \mathrm{dL}$ dan nilai range dalam hasil pemeriksaan ini didapatkan nilai minimum $4 \mathrm{mg} / \mathrm{dL}$ dan nilai maksimum $11 \mathrm{mg} / \mathrm{dL}$.

\section{BAHASAN}

Pada penelitian ini, dari 25 orang responden terdapat 19 responden (76,0\%) memiliki kadar urea nitrogen darah yang normal, diikuti 6 responden (24,0\%) yang memiliki kadar urea nitrogen darah yang rendah, sedangkan kadar urea nitrogen darah yang tinggi tidak ada (0\%). Pada penelitian ini didapati 6 responden (24,0\%) memiliki kadar urea nitrogen darah yang rendah. Hal ini menunjukkan bahwa pada vegetarian lacto-ovo juga merupakan salah satu diet tinggi protein yang menyebabkan keseimbangan nitrogen negatif sehingga kadar urea darah di bawah rentang normal.

Pada penelitian ini didapati 19 responden (76,0\%) memiliki kadar urea nitrogen darah normal. Hal ini menunjukkan bahwa pada vegetarian lacto-ovo yang hanya mengonsumsi protein nabati dan protein hewani dari susu dan telur tidak mengalami kekurangan protein sehingga keseimbangan nitrogen normal.

Pada penelitian ini tidak didapatkan responden yang memiliki kadar urea tinggi. Asupan protein yang banyak pada orang nonvegetarian menyebabkan kadar urea biasanya berada diatas rentang normal, ${ }^{10}$ Pada penelitian ini tidak didapatkan responden dengan kadar urea tinggi karena responden yang dipakai ialah vegetarian lacto-ovo yang hanya mendapat asupan protein dari kacang-kacangan, susu, dan telur.

Vegetarian lacto-ovo adalah diet yang tidak mengonsumsi segala jenis daging, baik daging ternak, unggas, dan ikan namun masih mengonsumsi sumber protein hewani dari susu dan telur dan mengonsumsi segala sumber protein nabati dari kacang-kacangan. ${ }^{11}$ Hal ini memengaruhi kadar urea dalam darah, karena kadar urea menggambarkan jumlah asupan protein, keseimbangan antara pembentukan protein dan katabolisme protein. ${ }^{9}$

Keseimbangan nitrogen adalah perbedaan antara jumlah nitrogen yang masuk ke dalam tubuh setiap hari (terutama dari protein makanan) dan jumlah senyawa bernitrogen yang keluar melalui air kemih, keringat, tinja, dan sel-sel yang terlepas. ${ }^{12}$

Jumlah protein yang dibutuhkan untuk menjaga keseimbangan nitrogen yakni 28 g/hari untuk orang yang berbobot $70 \mathrm{~kg}$ atau 0,4 g/kgBB/hari. Jika protein berasal dari gandum, maka pemasukan harian harus ditingkatkan sampai sekitar 40 g/hari untuk orang berbobot $70 \mathrm{~kg}$. Jumlah protein yang diperlukan oleh anak-anak dalam masa pertumbuhan lebih banyak, yakni sekitar 0,6 g/kgBB/hari. Pada demam, sepsis, operasi, trauma, dan luka dapat meningkatkan katabolisme protein, 
sehingga untuk menjaga keseimbangan nitrogen diperlukan protein, yakni 1,5-2 g/kgBB/hari. ${ }^{10,13}$

Urea nitrogen adalah hasil akhir dari metabolisme nitrogen. Nitrogen didapatkan dari asam amino yang berasal dari protein. ${ }^{8,9}$ Menurut hasil penelitian William et al. (2004) diet tinggi protein dapat menimbulkan keseimbangan nitrogen positif atau normal, namun kadang-kadang diet tinggi protein dengan nilai biologi rendah menimbulkan keseimbangan nitrogen negatif. Menurut hasil penelitian Sawe et al. ${ }^{14}$ diet tinggi protein dengan nilai biologis rendah dapat menimbulkan keseimbangan nitrogen negatif pada penderita penyakit ginjal kronik. ${ }^{14}$

\section{SIMPULAN}

Berdasarkan hasil penelitian pada 25 orang vegetarian lacto-ovo dapat disimpulkan bahwa sebagian besar memiliki kadar urea darah normal, sebagian kecil memiliki kadar urea darah yang rendah, sedangkan untuk kadar urea darah yang tinggi tidak ada

\section{SARAN}

1. Bagi masyarakat agar dapat memperhatikan pola makan yang sehat dengan menyeimbangkan jumlah asupan protein.

2. Bagi institusi terutama pendidikan agar lebih banyak melakukan penelitian tentang pola makan vegetarian terutama pada vegetarian lacto-ovo, karena penelitian-penelitian mengenai pola makan vegetarian terutama pada vegetarian lacto-ovo masih sangat minim.

3. Bagi para peneliti yang tertarik untuk melakukan penelitian serupa sebaiknya menghitung jumlah asupan protein yang masuk ke dalam tubuh dan perlu menambah jumlah responden.

\section{DAFTAR PUSTAKA}

1. Susianto, Wijaya H, Mailoa H. Diet enak ala vegetarian. Jakarta: Penebar Plus,
2008; p. 6.

2. Loma Linda University. The Vegetarian Food Pyramid. [cited 2015 Oktober 10]. Available from: http://www.vegetariannutrition.org/foo d-pyramid.pdf.

3. Universitas Sumatera Utara. Vegetarian. [cited 2015 Oktober 10]. Available from:

http://repository.usu.ac.id/bitstream/123 456789/22426/4/Chapter\%20II.pdf.

4. Universitas Indonesia. Vegetarian. [cited 2015 Oktober 10]. Available from: http://lib.ui.ac.id/file?file=digital/12342 6-S-5529-Faktor...Literatur.pdf

5. Nurheti Y. The Vegetarian Way. Yogyakarta: CV Andi, 2009.

6. Fikawati S, Wahyuni D, Syafiq A. Status gizi ibu hamil dan berat lahir bayi pada kelompok vegetarian. [cited 2015 Oktober 10]. Available from: http://journal.ui.ac.id/index.php/health/ article/view/1299/1188.

7. Marsh KA, Munn EA, and Baines SK. Protein and vegetarian diets. MJA. 2013;199(Suppl 4):S7-S10.

8. Suhardjo, Clara MK. Prinsip-prinsip Ilmu Gizi. Yogyakarta: Kanisius, 1992.

9. Herper H. A., VW Rodwell, PA Mayes. Biokimia Review of Physiological Chemistry. California: Lange Medical Publication; 1979.

10. Almatsier S. Penuntut diet. Jakarta: PT Gramedia Pustaka Utama; 2006. H. 25.

11. Universitas Muhammadiyah Semarang. Ureum. [cited 2015 October 11]. Available from:

http://digilib.unimus.ac.id/files/disk1/1 03/jtptunimus-gdl-datiastuti-5150-2bab2.pdf.

12. Nix S. Williams' Basic Nutrition \& Diet Terapi (12th ed). China: Elsevier Mosby, 2004; p. 46.

13. Ngili Y. Biokimia Metabolisme dan Biogenetika (1st ed). Yogyakarta: Graha Ilmu, 2009; p. 239-45.

14. Sawe A, Suryani As, Satriono R. Korelasi diet rendah protein terhadap keseimbangan nitrogen pada pasien penyakit ginjal kronik. [cited 2016 januari 10]. Available from: http://pasca.unhas.ac.id/jurnal/files/cd3 948cdd006ac562c61c36581b2c64f.pdf. 